\title{
Analysis of Foreign and Domestic Investment on Economic Growth in Nigeria (1980-2013)
}

Ibrahim $\mathrm{W}^{*}$ and Okunade, Sheu $\mathrm{A}^{\dagger}$

\begin{abstract}
Several factors have hampered economic growth in Nigeria, though there has been improvement in the recent times. Nevertheless, it remains fragile and is not strong enough to significantly reduce the prevailing level of poverty in the country. Against this backdrop, the study investigates the relationship between foreign and domestic investment on Economic growth in Nigeria, during the period 1980-2013, using Vector Error Correction Model (VECM). The study finds out that foreign and domestic investment have a strong influence both in short and long run, on the economic growth of Nigeria. The result shows unidirectional long-run causality between domestic investments to real GDP in Nigeria. Also, there is unidirectional long-run causality between exchange rate and real GDP in Nigeria. The result implies that change in current GDP is better explained by domestic investment and exchange rate rather than national income, foreign direct investment and credit to private sector. Hence, the government may encourage foreign investors to invest in the high risk areas, where the domestic investment lacks the technology and experiences needed.
\end{abstract}

Department of Economics, Al-hikmah University, Ilorin; ibraheed@alhikmah.edu.ng; olafuhad@yahoo.com

$\dagger$ Economics Department, University of Ibadan; okunade_sheu@yahoo.com 
Keywords: Foreign direct investment, Domestic investment, Credit to private sector, Exchange rate, National income and gross domestic product.

\section{Introduction}

Investment plays an important role in global business. It provides a firm with new markets and marketing channels, cheaper production facilities, assess to new technology and products, skills and financing for a host country or the foreign firm which receives the investment. It can also provide sources of new technologies, capital processes, products, organizational technologies and management skills, and as such can provide a strong impetus to economic development.

The recent debate on African economic development has devoted much attention to the role of external resource inflows, including foreign direct investment (FDI) and their potential contribution to accelerating growth and progress towards reaching development goals in Africa (UNECA, 2006). According to Ndikumana (2003), recent evidence indicates that FDI to African countries has been on the rise, especially since the 1990s, consistent with the general trend of private capital flows in developing regions. Domestic investment is claimed to be the most important source of economic growth and also an effective instrument in creating jobs for an economy. Domestic investment plays a dual role in the economy as part of aggregate demand and enlarges a nations stock of productive assets.

The main reason for embarking on this study came from a study carried out on Malaysia by Hooi Hooi Lean and Bee Wah Tan (2011), they investigate similar issues using data from Malaysia, and their result shows that FDI has positive impact on economic growth, while domestic investment is negatively affecting the economic growth in the long-run. The choice of Nigeria for this study is due to the fact that, a few studies on Nigeria did not test the causality between the variables. Hence, an assessment of the effect of foreign and domestic investment on the Nigerian economy is critical, in estimating the growth path of Nigeria as a developing country. Nigeria has been facing challenges with investment policy 
and economic growth, it is imperative to examine whether the result obtained in Malaysia is similar or different using data from Nigeria. This study contributes to the debate by providing further evidence on the determinants of foreign and domestic investment on economic growth in Nigeria.

\section{Study background}

At the macroeconomics level, investment expenditure in Nigeria in terms of financing is structured into domestic and foreign segments depending on sources of finance and to a lesser extent, management. At the domestic level, investment is further categorized into public and private sector investment expenditures. Foreign investment is further divided into foreign direct and portfolio investments, whether such expenditure is financed by private or official sources of capital. Investment could also be evaluated from the sectorial distribution point of view, in which case, each group of activity sectors of the gross domestic product is examined to measure the quantum of investment expenditure received over time. According to IMF (2008), foreign direct investment is defined as an investment involving a long-term relationship and reflecting a lasting interest and control by a resident firm in the economy of the host country. Matjekana (2002) noted that FDIs are broadly classified in terms of the directions of the flows, namely inward and outward. He based this classification on the types of restrictions of these investments. He defined inward FDI as investment in which foreign capital is invested in local resources and outward FDI as investment of local capital invested in foreign countries. As we have observed in the literature, FDI can also be divided into horizontal and vertical FDI. According to Fedderke and Romm, (2006), horizontal FDI refers to a case in which Multinational Corporations (MNCs) have their headquarters in their home country and have production plants both at home and abroad that produce the same goods. On the other hand, they define vertical FDI as investment in which Multinational Corporations (MNCs) portion different stages of production by having their headquarters in their home country and production plants in different foreign countries. Alternatively, Domestic investment is the acquisition of income-producing assets within the 
economy rather than abroad. Physical assets particularly add to the total capital stock. Boosting economic development requires higher rates of economic growth than domestic savings can provide. According to World Bank (2007), countries with the highest investment rates are not necessarily the one with highest savings rate. The role of domestic savings in the investment process is positive and long-term relationship between savings and investment tend to be strong. While short-term investment is encouraged by external sources of fund, long term investment is driven more by domestic forces.

\section{Theories of Investment}

- Keynes theory- The theory assumed that the expected return on investment is intrinsically volatile in view of the uncertainty that accompanies the main determinant of investment returns. But this is especially as far as private investment is concerned. The difference between the realized marginal efficiency of capital and the rate of interest is the opportunity cost of investment.

- Accelerator theory - This theory explains why a slowdown in growth of GDP can lead to negative growth in subsequent period through a fall in investment spending. It suggests that increase in output lead to increase in investment. It follows from the fact that the machinery and factories are a derived one. While new capital equipment is being built and installed, investment expenditure has taken place. If the desired stock of capital good increases, there will be an investment boom which will translate to increased GDP in that economy. This makes investment depend on changes in final demand, and hence changes in GDP.

- Neoclassical theory - The restrictive assumptions of the accelerator model resulted in the formation of the neoclassical theory by Hall and Jorgenson (1971).The optimal level of investment stock depends on the output level and user cost of capital, which in turn depends on the price of capital good, the real rate of interest and the depreciation rate. 
- Tobin's Q theory-This theory was postulated as a result of the inconsistency in the assumptions of perfect competition and exogenously determined output in the neoclassical theory. Tobin's Q theory emphasizes the relationship between the increase in the value of the firm due to the installation of additional capital and its replacement cost. Therefore, investment is a function of the difference between the market value of the additional unit of capital and its replacement cost.

\section{Literature review}

The extent to which FDI inflows enhances economic growth depends on the degree of complementary and substitutionary relationship between FDI inflows and domestic investment (De Mello, 1999).Therefore, attracting more FDI remains a desirable objective, but in order to achieve this there is a need to make Nigeria more attractive to foreign investors. On the other hand, domestic investment is claimed to be the most important source of economic growth and also an effective instrument in creating jobs for an economy. According to Firebaugh (1992), domestic investment is more likely to build relationship within the domestic industries. Apart from this domestic investment plays a dual role in the economy as part of aggregate demand and enlarges a nation's stock of productive assets. Thus, it is believed that domestic investment is an important factor in accounting for business cycles and the policy makers would now consider domestic investment when reforming their policies on investment sources. Hence, there is need to study empirically the broad relationship between foreign and domestic investment on Economic growth in Nigeria.

There have been a number of studies that have examined the relationship between economic growth, FDI inflows, and DI together. Choe (2003) investigated the relationship among the FDI inflows, DI and economic growth in 80 countries during the period 1971-1995 by using panel VAR model, found that there was a bidirectional causality between FDI inflows and economic growth, a unidirectional causality from economic growth to DI. $\mathrm{Xu}$ and Wang (2007) examined the effects of FDI inflows on China's DI, exports, imports, and GDP growth during the period 1980-1999. 
They found that there was a complementary relationship between FDI inflows and DI; FDI inflows also had a positive effecton economic growth. Bilgili et al. (2007) investigated the relationship between FDI inflows, DI, and economic growth in Turkey during the period 1992-2004 by using VAR analysis. They found that there was bidirectional causality between DI and economic growth. Tang et al. (2008) investigated the relationship between FDI inflows, DI and economic growth in China during the period 1988-2000 by using a multivariate VAR system and cointegration. They found that there was complementary relationship between FDI inflows and DI and there existed bidirectional causality between GDP and DI and a unidirectional causalityfrom FDI inflows to GDP and that DI had a greater impact on growth than FDI inflows did. Almasaied et al. (2008) examined the relationship between FDI inflows, DI and economic growth in Association of Southeast Asian Nations (ASEAN) during the period 1968-2002 by using ARDL cointegration. They found that FDI inflows and DI had a positive significant effect on economic growth. Elboiashi et al (2009) examined the relationship between FDI inflows, DI and economic growth in Egypt, Morocco and Tunisia during the period 1970-2006 by using cointegration test and causality test. They found that FDI inflows had a short run negative effect and long run positive effect on both DI and economic growth. Additionally they found that there was a unidirectional causality between FDI inflows and economic growth in Egypt and Morocco and bidirectional causality between FDI inflows and economic growth in Tunisia and FDI inflows crowded in DI in the short term while FDI inflows crowded out DI in the short term. Adams (2009) examined the effect of FDI inflows and DI on economic growth in Sub-Saharan Africa during the period 1990-2003 by using panel analysis and found that DI was positive and significantly correlated with economic growth in both the OLS and fixed effects estimation, while FDI was positive and significant only in the OLS estimation and FDI inflows crowded out DI. Chang (2010) examined the relationship among the FDI inflows, domestic capital and economic growth in Taiwan during the 1981-2008 by using threshold error-correction approach, found that there exist a unidirectional causality from economic growth to DI and from DI to FDI inflows and FDI inflows had a positive effect on economic growth and FDI inflows crowded in 
domestic investment. Ghazali (2010) investigated the relationship between FDI inflows, DI and economic growth in Pakistan during the 1981-2008 by using cointegration and causality test, found that there was a bidirectional causality between FDI inflows and DI; DI and economic growth; a unidirectional causality between FDI inflows and economic growth in the long term.Lean and Tan (2011) used Granger causality to examine the relationship between FDI inflows, DI and economic growth in Malaysia during the period 1970-2009 by using Johansen-Juseliuscointegration test and Granger causality test. They found that FDI inflows had a positive impact on economic growth, while DI had a negative impact on economic growth in the long term and there existed a complementary relationship between FDI inflows and DI, in other words FDI inflows crowded in DI. They also reached the finding that there was a unidirectional causality from DI to FDI inflows and from economic growth to FDI inflows in the short term. Chakraborty and Mukherjee (2012) examined the relationship between FDI inflows, DI and economic growth in India by using cointegration and causality tests and they found that there was a unidirectional causality from economic growth to FDI inflows and from FDI inflows to DI. Mohamed et al. (2013) examined the relationship between economic growth and FDI inflows, DI and also investigated the relationship between FDI inflows and DI in Malaysia during the period $1970-2008$ by using vector error correction model, impulse response function and variance decomposition analysis. They found that there existed bidirectional causality between DI and economic growth and no causality between FDI inflows and economic growth in the long run while there existed a crowding-in effect between FDI inflows and DI in the short run. Sooreea-Bheemul and Sooreea (2013) investigated the relationship between FDI inflows, exports, DI and economic growth in 28 developing and emerging countries during the 19891998 period by using panel Granger causality tests. They found that there was a unidirectional causality from economic growth to DI and bidirectional causality between all other variable pairs. Chowdhary and Kushwaha (2013) used Granger causality to investigate the relationship among FDI inflows, DI and economic growth in India during the period 1992-2012 and they found that there was bidirectional causality between DI and economic growth 
and no causality between FDI inflows and economic growth; FDI inflows had no effect on DI. Most of the studies in the literature such as Mun et al. (2008), Heteşet al. (2009), Anwar and Nguyen (2010), Chang (2010), Tiwari and Mutascu (2011), Asghar and Nasreen (2011), Lean and Tan (2011) and Soumia and Abderrezzak (2013) found that FDI inflows have had a positive impact on economic growth, while relatively few studies such as Mencinger (2003), Saqib et al. (2013), and Carkovic and Levine (2002) found that FDI inflows have had a negative impact on economic growth.

This study seeks to contribute to literature by using time series Nigeria data because most of the studies either use cross sectional or panel data to investigate the relationship between FDI, DI and economic growth. Also, most of the studies did not test for causality between variables. Obviously, the relationship between foreign and domestic investment and economic growth remains an ambiguous question. Against this backdrop, the analysis of causal relationship among the variables used is very important for policy makers to design the appropriate investment policy.

\section{Methodology and Model specification}

In line with the model of HooiHooi Lean and Bee Wah Tan (2011);

$\ln Y_{t}=\beta_{0}+\beta_{1} \ln F D I+\beta_{2} \operatorname{lnDI}+\varepsilon_{t}$

Where $\ln \mathrm{Y}_{\mathrm{t}}$ is real GDP, $\operatorname{lnFDI} I_{t}$ is net $\mathrm{FDI}_{t}$ inflows and $\ln \mathrm{DI}_{t}$ is domestic investment, $\beta_{0}$ is constant and $\varepsilon_{t}$ is error term. Hooi Hooi Lean and Bee Wah Tan (2011) opined that foreign and domestic investments are inevitable in economic growth of a nation.

Explaining growth in developing countries have centered on the standard model based on the Solow growth theory. In this framework, the capital-output and savings-investment flow equilibrium is of prime importance for output determination, with some assumption about technology. Where there is substitution between capital and labor, as in the Solow model, a more satisfactory postulation then depends on capital and labor inputs simultaneously. Thus, the basic Cobb-Douglas type production function is estimated as follows:

$\mathrm{Y}=\mathrm{f}(\mathrm{A}, \mathrm{K}, \mathrm{L})=\mathrm{AL}$ 
Where, $\mathrm{Y}$ is actual output, $\mathrm{K}$ is the capital stock, $\mathrm{L}$ is the labor supply, and A is the total factor productivity. The stock of capital is financed from different sources, domestic and external, including debt and non-debt categories. Thus, the model below is formulated:

$\mathrm{RGDP}=\mathrm{a}_{0}+\mathrm{a}_{1} \mathrm{FDI}+\mathrm{a}_{2} \mathrm{DI}+\mathrm{a}_{3} \mathrm{CPS}+\mathrm{a}_{4} \mathrm{EXR}+\mathrm{a}_{5} \mathrm{NI}+\mathrm{U}_{\mathrm{t}}$

Where: $\mathrm{RGDP}=$ gross domestic product, $\mathrm{FDI}_{\mathrm{t}}=$ foreign investment, $\mathrm{DI}_{\mathrm{t}}=$ domestic investment, $\mathrm{CPS}_{\mathrm{t}}=$ credit to private sector, $\mathrm{EXR}_{\mathrm{t}}=$ exchange rate, and $\mathrm{NI}_{\mathrm{t}}=$ national income. And $\mathrm{a}_{0}$ is intercept, $a_{1}$ too $_{5}$ is slope of coefficient and $U_{t}$ is the stochastic term. The data of all the variables are sourced from the World development Indicator (WDI 2014).A

Priori expectation: $\mathrm{a}_{1}>0, \mathrm{a}_{2}>0, \mathrm{a}_{3}<0, \mathrm{a}_{4}<0, \mathrm{a}_{5}<0, \mathrm{a}_{6}>0$.

\section{Causality Test}

If however, it is found that the integrated variables co integrate, then the equation can be augmented as follows:

$\Delta R G D P_{t}=\alpha_{1 j}+\sum_{k=1}^{m} \alpha_{11 k} \Delta R G D P_{t-k}+\sum_{k=1}^{m} \alpha_{12 k} \Delta \mathrm{FDI}_{t-k}+$ $\sum_{k=1}^{m} \alpha_{13 k} \Delta \mathrm{DI}_{t-k}+\sum_{k=1}^{m} \alpha_{14 k} \Delta C P S_{t-k}+\sum_{k=1}^{m} \alpha_{15 k} \Delta E X R_{t-k}+$ $\sum_{k=1}^{m} \alpha_{16 k} \Delta N I_{t-k}+\lambda_{1 k} E C T G D P_{t-k}+u_{1 t} \ldots \ldots \ldots \ldots \ldots$

$\Delta F D I_{t}=\alpha_{2 j}+\sum_{k=1}^{m} \alpha_{21 k} \Delta R G D P_{t-k}+\sum_{k=1}^{m} \alpha_{22 k} \Delta \mathrm{FDI}_{t-k}+$ $\sum_{k=1}^{m} \alpha_{23 k} \Delta \mathrm{DI}_{t-k}+\sum_{k=1}^{m} \alpha_{24 k} \Delta C P S_{t-k}+\sum_{k=1}^{m} \alpha_{25 k} \Delta E X R_{t-k}+$ $\sum_{k=1}^{m} \alpha_{26 k} \Delta N I_{t-k}+\lambda_{2 k} E C T G D P_{t-k}+u_{2 t} \ldots \ldots \ldots \ldots \ldots .$.

$\Delta D I_{t}=\alpha_{3 j}+\sum_{k=1}^{m} \alpha_{31 k} \Delta R G D P_{t-k}+\sum_{k=1}^{m} \alpha_{32 k} \Delta \mathrm{FDI}_{t-k}+$ $\sum_{k=1}^{m} \alpha_{33 k} \Delta \mathrm{DI}_{t-k}+\sum_{k=1}^{m} \alpha_{34 k} \Delta C P S_{t-k}+\sum_{k=1}^{m} \alpha_{35 k} \Delta E X R_{t-k}+$ $\sum_{k=1}^{m} \alpha_{36 k} \Delta N I_{t-k}+\lambda_{3 k} E C T G D P_{t-k}+u_{4 t} \ldots \ldots \ldots \ldots \ldots \ldots$

$\Delta C P S_{t}=\alpha_{4 j}+\sum_{k=1}^{m} \alpha_{41 k} \Delta R G D P_{t-k}+\sum_{k=1}^{m} \alpha_{42 k} \Delta \mathrm{FDI}_{t-k}+$

$\sum_{k=1}^{m} \alpha_{43 k} \Delta \mathrm{DI}_{t-k}+\sum_{k=1}^{m} \alpha_{44 k} \Delta C P S_{t-k}+\sum_{k=1}^{m} \alpha_{45 k} \Delta E X R_{t-k}+$ $\sum_{k=1}^{m} \alpha_{46 k} \Delta N I_{t-k}+\lambda_{4 k} E C T G D P_{t-k}+u_{5 t} \ldots \ldots \ldots \ldots \ldots \ldots 1.6$

$\Delta E X R_{t}=\alpha_{5 j}+\sum_{k=1}^{m} \alpha_{51 k} \Delta R G D P_{t-k}+\sum_{k=1}^{m} \alpha_{52 k} \Delta \mathrm{FDI}_{t-k}+$ $\sum_{k=1}^{m} \alpha_{53 k} \Delta \mathrm{DI}_{t-k}+\sum_{k=1}^{m} \alpha_{54 k} \Delta C P S_{t-k}+\sum_{k=1}^{m} \alpha_{55 k} \Delta E X R_{t-k}+$ $\sum_{k=1}^{m} \alpha_{56 k} \Delta N I_{t-k}+\lambda_{5 k} E C T G D P_{t-k}+u_{6}$

$\Delta N I_{t}=\alpha_{6 j}+\sum_{k=1}^{m} \alpha_{61 k} \Delta R G D P_{t-k}+\sum_{k=1}^{m} \alpha_{62 k} \Delta \mathrm{FDI}_{t-k}+$ $\sum_{k=1}^{m} \alpha_{63 k} \Delta \mathrm{DI}_{t-k}+\sum_{k=1}^{m} \alpha_{64 k} \Delta C P S_{t-k}+\sum_{k=1}^{m} \alpha_{65 k} \Delta E X R_{t-k}+$ $\sum_{k=1}^{m} \alpha_{66 k} \Delta N I_{t-k}+\lambda_{6 k} E C T G D P_{t-k}+u_{7 t} \ldots \ldots \ldots \ldots \ldots 1.8$ 


\section{Analysis of result}

\begin{tabular}{|l|c|c|c|c|c|c|}
\hline \multicolumn{1}{|c|}{ Level } & GDP & FDI & DI & CPS & EXR & NI \\
\hline ADF & 1.040 & -1.923 & -0.005 & -2.380 & -1.808 & -2.293 \\
\hline PP & 1.101 & -2.624 & -0.534 & -2.157 & -1.926 & -1.124 \\
\hline Crit. Value (5\%) & -2.960 & -2.976 & -2.960 & -2.960 & -2.960 & -3.563 \\
\hline $1^{\text {st }}$ Difference & GDP & FDI & DI & CPS & EXR & NI \\
\hline ADF & -6.737 & -4.764 & -3.820 & -5.421 & -4.764 & -6.105 \\
\hline PP & -14.228 & -4.764 & -3.725 & -7.429 & -4.764 & -7.877 \\
\hline Crit. Value (5\%) & -2.972 & -2.972 & -2.972 & -2.972 & -2.972 & -3.563 \\
\hline
\end{tabular}

Fig 1.0: Unit root result

Source: computed by researcher using E-view 7.0

The ADF and PP test result in figure 1.0, shows that null hypothesis of unit-roots for GDP, FDI, DI, CPS, EXR and NI cannot be rejected at levels but can be rejected at first difference of $5 \%$ critical value respectively. This means that the variables are non-stationary at levels, but are stationary at first difference in both ADF and PP test.

\begin{tabular}{|c|c|c|c|c|}
\hline $\begin{array}{l}\text { Hypothesized } \\
\text { No. of CE(s) }\end{array}$ & $\begin{array}{l}\text { Eigen } \\
\text { Value }\end{array}$ & $\begin{array}{c}\text { Trace } \\
\text { Statistic }\end{array}$ & $\begin{array}{c}0.05 \\
\text { Crit. Value }\end{array}$ & Probability \\
\hline None ${ }^{*}$ & 0.753256 & 125.6832 & 95.75366 & 0.0001 \\
\hline At most $1^{*}$ & 0.652160 & 83.70112 & 69.81889 & 0.0026 \\
\hline At most $2^{*}$ & 0.548534 & 52.02074 & 47.85613 & 0.0193 \\
\hline At most 3 & 0.381980 & 28.16310 & 29.79707 & 0.0762 \\
\hline At most 4 & 0.299324 & 13.72605 & 15.49471 & 0.0908 \\
\hline At most 5 & 0.096813 & 3.054780 & 3.841466 & 0.0805 \\
\hline $\begin{array}{l}\text { Hypothesized } \\
\text { No. of CE(s) }\end{array}$ & $\begin{array}{l}\text { Eigen } \\
\text { Value }\end{array}$ & $\begin{array}{c}\text { Max-Eigen } \\
\text { Statistic }\end{array}$ & $\begin{array}{c}0.05 \\
\text { Crit. Value }\end{array}$ & Probability \\
\hline None* & 0.753256 & 41.98206 & 40.07757 & 0.0301 \\
\hline At most $1^{*}$ & 0.652160 & 31.68038 & 33.87687 & 0.0894 \\
\hline At most 2 & 0.548534 & 23.85765 & 27.58434 & 0.1398 \\
\hline At most 3 & 0.381980 & 14.43705 & 21.13162 & 0.3302 \\
\hline At most 4 & 0.299324 & 10.67127 & 14.26460 & 0.1715 \\
\hline At most 5 & 0.096813 & 3.054780 & 3.841466 & 0.0805 \\
\hline
\end{tabular}

Fig 1.1: Cointegration result

Source: computed by researcher using E-view 7.0

The Johansen cointegration test result shown in figure 1.1, reveals that the null hypothesis of no cointegration can be rejected at $5 \%$ 
critical value for the trace and maximum-Eigen value test, since it indicates three cointegrating and one cointegrating equation in variables considered respectively. Therefore, Johansen cointegration test shows presence of a stable long run equilibrium relationship between the variables considered.

\begin{tabular}{|l|r|r|r|c|}
\hline Variable & Coefficient & Std. Error & \multicolumn{1}{c|}{ t-Statistic } & Prob. \\
\hline FDI & 0.005834 & 0.010552 & 0.552864 & 0.5851 \\
\hline DI & 0.091967 & 0.065113 & 1.412411 & 0.1697 \\
\hline EXR & 0.029964 & 0.017543 & 1.708009 & 0.0995 \\
\hline CPS & -0.094818 & 0.052204 & -1.816303 & 0.0809 \\
\hline NI & 0.878927 & 0.078347 & 11.21835 & 0.0000 \\
\hline C & 1.123298 & 0.705877 & 1.591351 & 0.1236 \\
\hline
\end{tabular}

Fig 1.2: OLS result

Source: computed by researcher using E-view 7.0

The static long run model for Nigeria which examines economic growth indicates that only changes in national income significantly influence economic growth in Nigeria. However, Exchange rate did not meet the a-prori expectations. All other variables met the aprori expectation but were not significant in influencing economic growth.

\begin{tabular}{|l|r|r|r|l|}
\hline \multicolumn{1}{|c|}{ Variable } & Coefficient & \multicolumn{1}{c|}{ Std. Error } & \multicolumn{1}{c|}{ t-Statistic } & Prob. \\
\hline $\mathrm{C}$ & 24.97098 & 0.229690 & 108.7160 & 0.0000 \\
\hline $\mathrm{D}(\mathrm{GDP}(-1))$ & 3.264038 & 2.284647 & 1.428684 & 0.1736 \\
\hline $\mathrm{D}(\mathrm{GDP}(-2))$ & 2.367445 & 2.172341 & 1.089813 & 0.2930 \\
\hline $\mathrm{D}(\mathrm{FDI}(-1))$ & -0.187288 & 0.103074 & -1.817018 & 0.0892 \\
\hline $\mathrm{D}(\mathrm{FDI}(-2))$ & -0.095596 & 0.107418 & -0.889948 & 0.3875 \\
\hline $\mathrm{D}(\mathrm{DI}(-1))$ & 0.586863 & 0.644683 & 0.910312 & 0.3771 \\
\hline $\mathrm{D}(\mathrm{DI}(-2))$ & 1.114675 & 0.823494 & 1.353593 & 0.1959 \\
\hline $\mathrm{D}(\mathrm{CPS}(-1))$ & -0.405795 & 0.647515 & -0.626697 & 0.5403 \\
\hline $\mathrm{D}(\mathrm{CPS}(-2))$ & 0.839166 & 0.626831 & 1.338744 & 0.2006 \\
\hline $\mathrm{D}(\mathrm{EXR}(-1))$ & -0.617397 & 0.501469 & -1.231177 & 0.2372 \\
\hline $\mathrm{D}(\mathrm{EXR}(-2))$ & -1.188392 & 0.561629 & -2.115976 & 0.0515 \\
\hline $\mathrm{D}(\mathrm{NI}(-1))$ & -3.216289 & 2.132196 & -1.508440 & 0.1522 \\
\hline $\mathrm{D}(\mathrm{NI}(-2))$ & -2.018643 & 2.156569 & -0.936044 & 0.3641 \\
\hline $\mathrm{ECM}(-1)$ & $-8.38 \mathrm{E}+10$ & $3.19 \mathrm{E}+12$ & -0.026231 & 0.9794
\end{tabular}

Fig 1.3: Over-parameterization result

Source: computed by researcher using E-view 7.0........ $\mathrm{R}^{2}=0.725621$ 
The result of the over-parameterized model presented in figure 1.3 above shows that the error correction term i.e. ECM (-1) is negative but not significant. Its coefficient implies that the speed of adjustment to equilibrium is high. The $\mathrm{R}^{2}$ signifies that all the explanatory variables in the model accounts for $73.6 \%$ total variation in GDP while the remaining $27.4 \%$ is attributed to the white noise residual.

\begin{tabular}{|l|r|r|r|r|}
\hline \multicolumn{1}{|c|}{ Variable } & \multicolumn{1}{c|}{ Coefficient } & \multicolumn{1}{c|}{ Std. Error } & \multicolumn{1}{c|}{ t-Statistic } & \multicolumn{1}{c|}{ Prob. } \\
\hline \multicolumn{1}{|c|}{ C } & 24.88694 & 0.202291 & 123.0252 & 0.0000 \\
\hline $\mathrm{D}(\mathrm{GDP}(-1))$ & 3.689017 & 1.554285 & 2.373449 & 0.0283 \\
\hline $\mathrm{D}(\mathrm{GDP}(-2))$ & 0.556647 & 0.885044 & 0.628949 & 0.5369 \\
\hline $\mathrm{D}(\mathrm{FDI}(-1))$ & -0.165301 & 0.069666 & -2.372751 & 0.0284 \\
\hline $\mathrm{D}(\mathrm{DI}(-2))$ & 1.078920 & 0.645581 & 1.671240 & 0.1111 \\
\hline $\mathrm{D}(\mathrm{CPS}(-2))$ & 0.643944 & 0.533766 & 1.206416 & 0.2425 \\
\hline $\mathrm{D}(\mathrm{EXR}(-1))$ & -0.692826 & 0.460717 & -1.503802 & 0.1491 \\
\hline $\mathrm{D}(\mathrm{EXR}(-2))$ & -0.904218 & 0.441928 & -2.046073 & 0.0548 \\
\hline $\mathrm{D}(\mathrm{NI}(-1))$ & -2.693247 & 1.644678 & -1.637553 & 0.1180 \\
\hline $\mathrm{ECM}(-1)$ & $-3.83 \mathrm{E}+11$ & $2.48 \mathrm{E}+12$ & -0.154384 & 0.8789 \\
\hline
\end{tabular}

Fig 1.4: Parsimonious result

Source: computed by researcher using E-view 7.0F-stat $=4.29$, Prob $=0.00361$ and $\mathrm{R}^{2}=0.670675$

The result of the parsimonious or preferred ECM shows that a mix of the explanatory variables is significant at 1 or 5 percent level. The value of FDI and national income are significant, and has negative influence on economic growth in Nigeria in the short run. The coefficient of determination indicated by $\mathrm{R}^{2}$ shows that about 67.1 percent of the variations in RGDP are explained within the model. The overall regression result measured by F-statistic 4.299 with probability of 0.00361 is significant, indicating a good fit of the model.

\begin{tabular}{|l|c|c|r|}
\hline Null Hypothesis: & Obs & F-Statistic & Prob. \\
\hline FDI does not Granger Cause GDP & 31 & 1.44493 & 0.2394 \\
\hline GDP does not Granger Cause FDI & 31 & 1.09798 & 0.3037 \\
\hline DI does not Granger Cause GDP & & 22.3034 & 6. E-05 \\
\hline GDP does not Granger Cause DI & 31 & 0.27642 & 0.6032 \\
\hline CPS does not Granger Cause GDP & 31 & 1.59656 & 0.2168 \\
\hline GDP does not Granger Cause CPS & 10.5058 & 0.0031 \\
\hline EXR does not Granger Cause GDP & 0.97182 & 0.3327 \\
\hline GDP does not Granger Cause EXR & 31 & 0.05355 & 0.8187 \\
\hline NI does not Granger Cause GDP & 2.35569 & 0.1360 \\
\hline GDP does not Granger Cause NI
\end{tabular}

Fig 1.5: Granger causality result

Source: computed by researcher using E-view 7.0 
The results reported in figure 1.5 using the F-stat value shows that no granger causality between FDI and GDP. Domestic investment granger cause real GDP. While the exchange rate granger cause real GDP. There is no granger causality between national income and real GDP. The result implies that change in current real GDP is better explained by domestic investment and exchange rate rather than national income, FDI and credit to private sector.

\section{Conclusion and Policy recommendation}

This study has focused on the relationship between foreign and domestic investment on economic growth in Nigeria. To achieve the objective of the study, we employed a battery of econometric techniques such as the Johansen-Juselius cointegration for long run analysis, error correction mechanism for short run analysis and the granger causality test. To allow for robustness, the study utilized variables which include: foreign direct investment, domestic investment, Credit to public sector, exchange rate, national income and gross domestic product. The study established the existence of a stable long run relationship between foreign and domestic investment and real GDP included in the model for the period under study. The ordinary least square results which also confirm the existence of a long run relationship reveal that national income significantly influences economic growth in the long run. However, this study infers that for foreign and domestic investment to propel economic growth depend on the variables used as proxy. The study also established an empirical evidence of a short run relationship in Nigeria, where FDI and national income has a negative influence on economic growth. The estimated coefficient indicates that about 38.3 percent of the errors in the short-run are corrected in the longrun. Therefore, it can be concluded there exists long and short run relationship between foreign and domestic investment and economic growth in Nigeria.

One of the main objectives of the government has been the stabilization of macroeconomic condition in order to enhance investment and growth of the economy. Unfortunately, the prospects of rapid economic growth have not been realized as the investment climate continued to be unfavorable. A number of constraints continued to prevent the realization of these objectives. 
Notable among these are: exchange rate volatility, paucity of investment capital, inadequate access to medium and long-term finance, inflationary pressure, poor infrastructure, debt overhang and debt services burden, inadequate fiscal and monetary incentives, and poor investment climate. To address these problems, there is a need for appropriate macroeconomic and sectorial policies to significantly increase domestic savings, investment and growth in the economy. The following measures are therefore recommended to correct the institutional and structural inefficiencies that characterize the Nigerian economy.

First, Government should ensure sound macroeconomic policy framework that would ensure an investor friendly environment which would guarantee the profitability of investments. Hence, there is a need to reduce the cost of doing business in Nigeria, improve the incentive structure, and enhance access to credit for the private sector to help enable the sector play a leading role in economic growth and development. These can only be achieved through vibrant regulatory and monetary policies, aimed at increasing deposit money banks' lending capacity. In addition to the current efforts of encouraging banks' lending to the private sector, the regulatory authorities should reduce the cash reserve requirements imposed on banks for prudential purposes. This will enhance banks credit creation. Second, the Nigeria financial system has to be healthy and efficient in order to improve savings and investment. The current oligopolistic structure of banking industry, in which a few banks control over 60 percent of the deposit market, should be discouraged through enhanced competition. Adequate financial and fiscal incentives should be provided to encourage investment output growth. Such incentives could be in form of investible funds at concessionary interest rates, tax holiday and import duty concessions.

In conclusion, the problem of low savings and lower investment in Nigeria has to be addressed. As noted by Soludo (1998), the problem may not necessarily be the dearth of domestic savings for investment but that of the flight of capital. The absence of conducive investment climate has led to risks associated with safety and productivity of capital. These risk elements also combine with the poor state of public infrastructure, corruption, high cost of 
doing business and complex regulatory environment to make investment in Nigeria less profitable. The fundamental challenge to government therefore lies in its ability to guarantee the safety of business, provide a competitive macro-environment as well as overhaul the economic infrastructure. Once these issues are properly addressed, Nigeria's investment threshold will rise and meaningful growth and development will take place.

\section{References}

Adams, S. 2009. Foreign Direct investment, domestic investment, and economic growth in Sub-Saharan Africa.Journal of Policy Modeling. 31(6):939-949.

Acar, S., B. Eris \& M. Tekce 2012. The effect of foreign direct investment on domestic investment: Evidence from MENA countries. European Trade Study Group 14th Annual Conference.Leuven, Belgium.

Agosin, M. R., \& R. Machado 2005. Foreign investment in developing countries: Does it crowd in domestic investment? Oxford Development Studies. 33(2):149-162.

Akinlo, A. E. 2004. Foreign direct investment and growth in Nigeria: An empirical investigation. Journal of Policy Modeling. 26(5):627-639.

Almasaied, S. W., A. Z. Baharumshah\& S. Rashid 2008. The impact of domestic and foreign direct investments on economic growth: Evidence from ASEAN countries. Pertanika Journal of Social Sciences \& Humanities. 16(2):239-255.

Anwar, S.\&L. PNguyen 2010.Foreign direct investment and economic growth in Vietnam. AsiaPacific Business Review. 16(12):183-202.

Asghar, N. \& S. Nasreen 2011. Relationship between FDI and economic growth in selected Asian countries: A panel data analysis. Review of Economics \& Finance.84-96.

Athukorala, P. P. A. 2003. The impact of foreign direct investment for economic growth: a case study in Sri Lanka. 9th International Conference on Sri Lanka Studies, Full Paper (No.092). 
Chakraborty, D.\&J. Mukherjee 2012. Is there any relationship between foreign direct investment, domestic investment and economic growth in India? A time series analysis. Review of Market Integration.4(3):309-337. http://dx.doi.org/10.1177/ 0974929213481712.

Chang, S. C. 2010. Estimating relationships among FDI inflow, domestic capital, and economic growth using the threshold error correction approach. Emerging Markets Finance ETrade.46(1):6-15. http://dx.doi.org/10.2753/REE1540496X460101

Choe JI 2003. Do foreign direct investment and gross domestic investment promote economic growth? Review of Development Economics. 7(1): 44-57.

Chowdhary, R., \& Kushwaha, V. (2013).Domestic investment, foreign direct investment and economic growth in India since economic reforms. Journal of Transformative Entrepreneurship, $1(2)$, $74-82$. http://dx.doi.org/10.14239/JTE.2013.01201

Engle R.F and C.W.F. Granger 1987.Co-integration and Error Correction: Representation, Estimation and Testing. Econometrica. 55(2):251-276.

Ghazali, A. 2010.Analyzing the relationship between foreign direct investment domestic investment and economic growth for Pakistan. International Research Journal of Financeand Economics. 47:123-131.

Li, X and X. Liu 2005. Foreign Direct Investment and Economic Growth: An increasingly Endogenous Relationship. World Development. 33(3):393-407.

Lim, D. 2001. Fiscal Incentives and Direct Foreign Investment in Less Developed Countries. Journal of Development Studies. 19(2):207-212. 
Matjekana K. S. M, 2002. Foreign Direct Investment Flows in the SADC Region in a Globalising Economic Environment. Rand Afrikaans University, Johannesburg.

Mun, H. W,T. K. Lin \& Y. K Man 2008. FDI and economic growth relationship: An empirical study on Malaysia. International Business Research. 1(2):11-18.

Ndikumana, L. 2003. Capital Flows, Capital Account Regimes, and Foreign Exchange Rate Regimes in Africa, in: United Nations Conference on Trade and Development (UNCTAD) Management of Capital Flows: Comparative Experiences and Implications for Africa, (Geneva:UNCTAD). 313-384.

Solow, R. M. 1956. A Contribution to the Theory of Economic Growth. Quarterly Journal of Economics. 70:65-94.

Soludo, C.C 1998. Investment in the growth process: A measure of the economist Ignorance in Africa, in rekindling investment for economic development in Nigeria proceedings of 1998 annual conference of the Nigeria economic society.

Soumia, Z. \& B. Abderrezzak 2013. The determinants of foreign direct investment and their impact on growth: Panel data analysis for AMU countries. International Journal of Innovation and Applied Studies.2(3):300-313.

UNCTAD, 2006.FDI from Developing and Transition Economies: Implications for Development. World Investment Report. 65.

World Bank 2002.Transnational Corporation and Export Competitiveness. UNTACD: New Yorkand Geneva.

Xu, B. 2000.Multinational enterprises, technology diffusion, and host country Productivity Growth. Journal of Development Economics.62:477-493.

Zhang, K. H 1999b. How does FDI interact with economic growth in a large developing country? The case of China. Economic System. 21(4):291- 304.

Zhang, K. H 2001. Does foreign direct investment promote economic growth? Evidence from East Asia and Latin America. 
Contemporary Economic Policy. 19(2):175-185. http:/ /dx.doi.org/ 10.1111/j.1465-7287.2001.tb00059.x.

Zhao, C. \& J. Du 2007.Causality between FDI and economic growth in China. Chinese Economy.40(6):68-82. http://dx.doi.org/ 10.2753/CES1097-1475400604. 